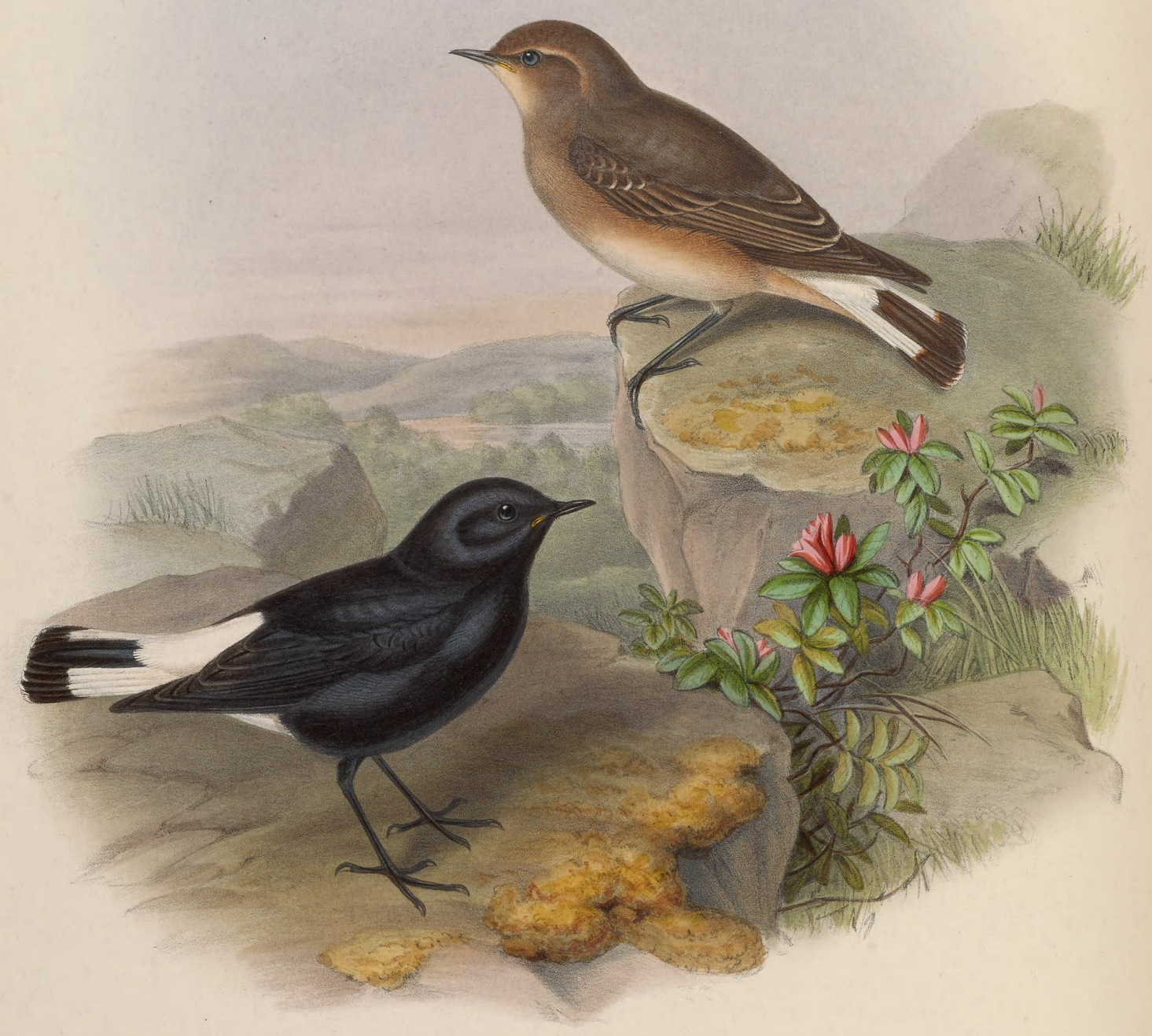




\title{
DROMOLAA OPISTHOLEUCA.
}

\author{
White-tailed Stone-Chat.
}

Saxicola opistholeuca, Strickl. in Jard. Cont. to Orn., 1849, p. 60. 10, fig.

- leucura, Blyth, Journ. Asiat. Soc. Calcutta, vol. xvi. p. 137.-Id. Cat. of Birds in Mus. Asiat. Soc. Calcutta, p. 167

leucuroides, Jerd. Birds of India, vol. ii. pt. i. p. 130.

I THINk Mr. Strickland was right in considering this bird to be different from M. Guérin's Saxicola leucuroides, and Mr. Jerdon mistaken in considering it identical with that species. I have at this moment examples of the Indian, the Nubian, and the Algerian birds before me; and although they bear a general resemblance in their colouring, still there are points of difference which I think would induce most ornithologists to regard them as distinct: these consist in the very feeble character of the bill of the Indian, compared with that of the Nubian and Algerian birds, and in the colouring of the tail, the apical three-fifths of the two central feathers and the tips of the lateral ones in the former being black, while in both the others the tips of the same feathers are pure white or merely clouded with blackish brown. Mr. Strickland was also of opinion that Mr. Blyth was in error in considering the present bird to be identical with the S. leucura; and his remarks on the subject are so judicious that I need make no apology for transcribing them.

"This is evidently the bird referred to as Saxicala leucura by Mr. Blyth, as he states it to differ from his S. picata only in having the breast and belly black, while in the latter species those parts are white. As I have before me specimens of S. picata, I can confirm Mr. Blyth's statement of the close agreement in size and coloration of these two birds. They form, in fact, a parallel case to that of the Saxicola aurita and S. stapazina of Southern Europe, which only differ in the presence or absence of black on the throat, and whose specific distinctness is still a matter of controversy among naturalists. It is very possible that some species of Saxicola may, at certain periods of life, assume additional portions of black or white into their plumage, just as many of the rufous Tchitrea acquire more or less of a white coloration in old age. This may perhaps account for the immense number of species of Saxicola described by Rüppell, Ehrenberg, and others as inhabiting the deserts of Africa and Western Asia. Conformably with this view, we find that, in a specimen of $\boldsymbol{S}$. opisthalenca before us, some of the black abdominal feathers are narrowly tipped with white, as if in the act of changing colour. Further researches, however, are required to decide this question, and meanwhile we have no choice but to regard $S$. opistholeuca as distinct from $S$. picata until their identity be proved.

"Saxicola opistholeuca agrees closely in coloration with $S$. leucura of Europe, but is considerably inferior in size. It also differs in having the lateral rectrices tipped with a continuous patch of black, while in a specimen of $S$. leucura, now before me, they have merely a longitudinal black spot on each side, separated by a white space, which extends to the extreme tips."

"This fine Stone-Chat," says Mr. Jerdon, " is not uncommon about Mhow, in Central India, in the cold weather; and I have seen it on the banks of the Nerbudda, near Mundleysur, but nowhere else. Its range probably extends throughout the North-western Provinces, having been killed near Agra and in Sindh. In summer it doubtless migrates to Tibet and Central Asia." Captain Boys procured specimens in Northern India; and Mr. Blyth states that it is common about Agra. It frequents bushes on the plains, but also comes into cantonments, and may be seen seated on the hedges or on the low trees bordering the roads. It descends to the ground to feed on insects, returning to its perches.

So little has been recorded respecting the differences, if any, between the sexes and between the adults and young of this species, that I am unable to say whether the brown bird represented in my Plate is a true female or not.

The male has the whole of the plumage of the body, both above and beneath, to the vent, and the wingcoverts deep black; primaries black on their external webs, greyish brown on the inner; upper and under tail-coverts white; two central tail-feathers white at the base, and black for the remainder of their length ; the lateral feathers white, tipped with black; irides dark brown; bill and feet black.

The figures are of the size of life. 


\section{$2 \mathrm{BHL}$ Biodiversity Heritage Library}

Gould, John. 1865. "White-tailed Stone-Chat, Dromolsea opistholeuca [PI. 27]." The Birds of Asia 4(XVII), -. https://doi.org/10.5962/p.323319.

View This Item Online: https://www.biodiversitylibrary.org/item/120503

DOI: https://doi.org/10.5962/p.323319

Permalink: https://www.biodiversitylibrary.org/partpdf/323319

\section{Holding Institution}

Smithsonian Libraries

\section{Sponsored by}

Smithsonian Institution Libraries

\section{Copyright \& Reuse}

Copyright Status: Not in copyright

This document was created from content at the Biodiversity Heritage Library, the world's largest open access digital library for biodiversity literature and archives. Visit BHL at https://www.biodiversitylibrary.org. 